\title{
Control of Anticarsia gemmatalis (Hübner: 1818) (Lepidoptera: Erebidae) and Chrysodeixis includens (Walker: 1858) (Lepidoptera: Noctuidae) Through Insecticides Applied to Soybean Seeds
}

\author{
E. C. S. Vieira ${ }^{1}$, C. J. Ávila ${ }^{1,2}$, L. M. Vivan ${ }^{3}$, I. F. Silva ${ }^{1}$, M. C. S. Vieira ${ }^{1} \&$ P. G. Silva ${ }^{1}$ \\ 1 Programa de Pós-graduação em Entomologia e Conservação da Biodiversidade, Universidade Federal da \\ Grande Dourados, Dourados, MS, Brazil \\ ${ }^{2}$ Empresa Brasileira de Pesquisa Agropecuária (Embrapa Agropecuária Oeste), Dourados, MS, Brazil \\ ${ }^{3}$ Fundação MT, Rondonópolis, MT, Brazil \\ Correspondence: E. C. S. Vieira, Programa de Pós-graduação em Entomologia e Conservação da Biodiversidade, \\ Universidade Federal da Grande Dourados, Dourados, MS, Brazil. Tel: 55-67-99939-3545. E-mail: \\ elizete.cavalcanteufgd@gmail.com
}

Received: August 27, 2019

Accepted: September 27, 2019

Online Published: November 15, 2019

doi:10.5539/jas.v11n18p88

URL: https://doi.org/10.5539/jas.v11n18p88

The research is financed by Fundação MT, Capes and EMBRAPA.

\begin{abstract}
Brazil is the second largest producer of soybeans in the world, with the state of Mato Grosso having the highest production in the country. The soybean crop faces major phytosanitary difficulties throughout its cultivation, as is the case of pest incidence, especially the defoliating caterpillars that can cause intense defoliation of soybean and affect its productivity. Thus, the objective of this work was to evaluate the effect of different insecticides when applied in soybean seed treatment, on leaf consumption and survival of Anticarsia gemmatalis (Lepidoptera: Erebidae) and Chrysodeixis includens (Lepidoptera: Noctuidae) caterpillars. For this purpose, two trials were installed in the field, one in the Juscimeira Municipality/MT and the other in the Municipality of Itiquira/MT. The soybean seeds were treated with the insecticides (in g a.i./ha): chlorantraniliprole (62.5), imidacloprid + thiodicarb $(75.0+25.0)$, fipronil $(50.0)$, thiamethoxam (70.0) and cyantraniliprole + thiamethoxam $(60.0+70.0)$ and a control treatment (without insecticide). Soybean leaflets were collected at different times after plant emergence and were offered to A. gemmatalis and $C$. includens caterpillars in the laboratory to evaluate leaf consumption and mortality. Cyantraniliprole + thiamethoxam $(60.0+70.0)$ and chlorantraniliprole (62.5) treatments were found to reduce leaf consumption of $A$. gemmatalis and $C$. includens caterpillars. The highest mortality values of $A$. gemmatalis and $C$. includens were observed in the treatment cyantraniliprole + thiamethoxam $(60.0+70.0)$, followed by chlorantraniliprole $(62.5)$ when compared to the control treatment. The results showed that the treatment of soybean seeds with insecticides can protect the crop against defoliation and provide control of defoliating caterpillars, these effects being more pronounced in sandy soils than in clay soils.
\end{abstract}

Keywords: defoliating caterpillars, Glycine $\max ($ L.), mortality, leaf consumption, seed treatment, soil

\section{Introduction}

With a world production of grains exceeding 360 million tons, the soybean crop (Glycine max L. Merr.) is very important economically (USDA, 2019). Grains of this leguminous are the main source of vegetable protein, an essential component in animal feed production, as well as widespread use in human food (Cattelan \& Dall'Agnol, 2018). Brazil is the second largest producer of soybeans in the world, growing about 35 million hectares in the 2018/2019 season, with the state of Mato Grosso having the largest production in the country (Lima et al., 2019). However, throughout the production cycle of the crop, there are phytosanitary factors that compromise its productivity. Among them, the constant presence of insect pests stands out, which can occur from sowing until the maturation stage of the grains, being characterized as one of the main limiting factors for the exploitation of the crop, and consequently, of its production (Ávila \& Schlick-Souza, 2015; Husch et al., 2018). 
Among the pest insects that occur in soybean, defoliating caterpillars stand out, which especially during the vegetative stage of the plants can cause defoliation and cause economic losses, as well as difficulty of control, since some species are more and more tolerant to the synthetic insecticides commonly used in this crop (Chang \& Hartman 2017). In addition, caterpillars of the species Chrysodeixis includens (Walker, 1858) (Lepidoptera: Noctuidae) due to the habit of remaining sheltered under the canopy of soybean plants staying less exposed to spraying with insecticides, thus compromising their control efficiency (Bernardi et al., 2012; Zulin et al., 2018). In addition, both $C$. includens and Anticarsia gemmatalis (Hübner, 1818) caterpillars (Lepidoptera: Erebidae) when feeding of soybean plants reduce the photosynthetically active leaf area, which may compromise the filling of the pods and, consequently, the productivity of the crop (Moscardi et al., 2012; Bortolotto et al., 2015; Specht et al., 2015; Santos et al., 2017a, 2017b).

There is a possibility of control of defoliating caterpillars in soybean cultivation through seed treatment and, consequently, reduce the damage caused by these insects especially in the initial stages of development of the plants, thus guaranteeing a better initial development of the crop with direct reflexes in its productivity (Balardin et al., 2011; Cox \& Cherney, 2011; Camargo et al., 2019).

Thus, seed treatment can reduce the number of insecticide sprays in soybean, especially in the vegetative phase of the crop, reducing the impact to the agroecosystem, and not compromising the development of the natural enemies' complex present in the crop (Castro et al., 2008). In addition, some insecticides may confer physiological effects on soybean, providing a more vigorous initial development of the plants, thus ensuring a better stand establishment and crop yield (Tavares et al., 2014; Tonin et al., 2014; Milosavljević et al., 2019).

Therefore, the objective of this work was to evaluate the effect of different treatments of soybean seeds with insecticide on the management of Anticarsia gemmatalis and C. includens.

\section{Method}

\subsection{Seeds Treatments}

Five insecticides registered for soybean cultivation in Brazil were evaluated (MAPA, 2019), consisting of the following treatments (in $\mathrm{g} \mathrm{a} . \mathrm{i} / 100 \mathrm{~kg}$ of seeds): $\mathrm{T} 1$ : chlorantraniliprole (62.5); T2: thiodicarb + imidacloprid (75 + 25); T3: fipronil (50); T4: thiamethoxam (70); T5: cyantraniliprole + thiamethoxam $(60+70)$ and T6: control treatment (without application of insecticide in seeds). All the soybean seeds used in the trials were also treated with the fungicides carbendazim + thiram $(15+35 \mathrm{~g}$ a.i./100 $\mathrm{kg}$ of seeds $)$ to avoid possible problems with pathogens, especially those present in the soil.

\subsection{Field Trials}

Soybean plants, in which the seeds were treated or not with insecticides, were used as food sources of the $A$. gemmatalis and C. includens caterpillars, coming from two distinct areas of the State of Mato Grosso, MT, Brazil, during the 2015/2016 season, as follows:

\subsubsection{Mirandópolis Farm}

Located in the municipality of Juscimeira, MT $\left(16^{\circ} 21^{\prime} 49.82^{\prime \prime} \mathrm{S}\right.$ and $\left.55^{\circ} 04^{\prime} 30.40^{\prime \prime} \mathrm{W}\right)$; has an altitude of 545 meters and soil characterized as Dystrophic Red Latosol of clayey texture (Table 1). The soybean cultivar "TMG 1180 RR" was used in the planting of this area, and the sowing was done with a spacing of 0.45 meter between the soybean lines. The fertilization of the area was 350 kilos of the formulated fertilizer 02-23-00 (NPK), applied in the base at the time of sowing, added with 150 kilos of $\mathrm{KCl}$, applied over the soil.

\subsubsection{São Miguel Farm}

Located in the municipality of Itiquira, MT $\left(17^{\circ} 10^{\prime} 02.3^{\prime \prime} \mathrm{S}\right.$ and $\left.54^{\circ} 37^{\prime} 15.6^{\prime \prime} \mathrm{W}\right)$, with an altitude of $522 \mathrm{~m}$ and soil with sandy texture (Table 1). Seeding was carried out using soybean cultivar "TMG 1179 RR", with a spacing of 0.45 meter in the soybean line. The fertilization consisted of $81 \mathrm{kilos} / \mathrm{ha}$ of $\mathrm{P}_{2} \mathrm{O}_{5}+94 \mathrm{kilos} / \mathrm{ha}$ of $\mathrm{K}_{2} \mathrm{O}+17$ $\mathrm{kilos} / \mathrm{ha}$ of sulfur (S) applied in the sowing line, plus $90 \mathrm{kilos} / \mathrm{hl}$ of $\mathrm{KCl}$, applied over the soil. 
Tabela 1. Components of the texture (clay, silt and sand) and organic matter (OM) of the soils of São Miguel Farm (Itiquira, MT) and Mirandópolis Farm (Juscimeira, MT) used for soybean cultivation

\begin{tabular}{llccc}
\hline Locality & Clay & Silt & Sand & $\mathrm{OM}^{\mathrm{a}}$ \\
\hline Fazenda São Miguel & -168.0 & 53.0 & 779.0 & 15.0 \\
Fazenda Mirandópolis & 567.0 & 150.0 & 283.0 & 33.0 \\
\hline
\end{tabular}

Note. ${ }^{\mathrm{a} O r g a n i c ~ m a t t e r . ~}$

\subsection{Laboratory Bioassays}

In the laboratory, leaf consumption and mortality of $A$. gemmatalis and $C$. includens caterpillars were evaluated when fed with soybean leaves treated with or without insecticides in the seeds from the two growing areas. For that, soybean leaves were collected at 7, 14, 21, 28 and 35 days after emergence of the plants in the experimental area. After collection, the leaves were initially hygienized in the laboratory and later, circular discs with $10 \mathrm{~mm}$ diameter were prepared and offered to newly hatched caterpillars of A. gemmatalis and $C$. includens, reared in the laboratory of the MT Foundation. Each caterpillar was confined in a test plate, containing the soybean leaf disc and kept at a temperature of $25 \pm 2{ }^{\circ} \mathrm{C}$, RH. $60 \pm 10 \%$ and 12-hour of photophase.

The leaf disc consumption and the mortality of caterpillars were determined every 7 days after the test installation. In order to evaluate the leaf consumption of $A$. gemmatalis and $C$. includens caterpillars, the area consumed in the leaf disc was estimated from 0 to $100 \%$ relative to the disk originally offered intact to the caterpillars. The trials were conducted in the completely randomized design with the six treatments and four replicates, being each replicate represented by 4 caterpillars (four test plates) of each caterpillar species.

The foliar consumption and mortality values of the caterpillars were submitted to analysis of variance (ANOVA) and, when a significant treatment effect was found, the means were compared by the Tukey test at 5\% of probability.

\section{Results}

The percentage of leaf area consumed (LAC) and mortality (M) of caterpillars of $C$. includens at 7 DAE (days after emergence) in the municipality of Itiquira were significant only for the treatment cyantraniliprole + thiamethoxam $(60+70 \mathrm{~g}$ a.i.) in relation to the control, which presented, respectively, lower leaf consumption and higher mortality of caterpillars (Table 2). In the municipality of Juscimeira, there was no significant influence on leaf consumption and mortality of $C$. includens caterpillars for all treatments applied in soybean seeds at all times of evaluation (Table 3). At 14 DAE, in the municipality of Itiquira, the highest percentage of $C$. includens defoliation was observed in the treatment with fipronil (50 g a.i.), which was not different from the control treatment, but was superior in comparison to chlorantraniliprole treatments (62.5 $\mathrm{g}$ a.i.) and cyantraniliprole + thiamethoxam $(60+70 \mathrm{~g}$ a.i. $)$, which also presented higher mortality of caterpillars (Table 2). At $21 \mathrm{DAE}$, cyanuthoheylamido + thiamethoxam $(60+70 \mathrm{~g}$ a.i. $)$ continued to present lower soybean defoliation intensity and higher larval mortality compared to control as well as thiodicarb + imidacloprid treatment (72.5 \pm 31.7 ). In the other evaluations (28 and $35 \mathrm{DAE}$ ) there was no significant difference between treatments evaluated for the intensity of defoliation and mortality of $C$. includens caterpillars (Table 2).

In the test conducted with $A$. gemmatalis caterpillars in the municipality of Itiquira, there was no significant effect of the treatments for leaf caterpillar consumption at 14 DAE. However, the mortality of caterpillars was $100 \%$ in the treatments chlorantraniliprole $(62.5 \mathrm{~g}$ a.i. $)$, fipronil $(50 \mathrm{~g}$ a.i. $)$ and cyantraniliprole + thiamethoxam $(60+70 \mathrm{~g}$ a.i. $)$, differing from the other treatments that did not present any mortality of caterpillars at this time (Table 4). At 21 DAE the leaf area consumed was again lower for chlorantraniliprole (62.5 g a.i.) and cyantraniliprole + thiamethoxam $(60+70 \mathrm{~g}$ a.i. $)$ compared to the control and thiodicarb + imidacloprid $(72.5+$ $31.7 \mathrm{~g}$ a.i.), while that the mortality of caterpillars was higher in all chemical treatments applied in the seeds in relation to the control (Table 4).

At 28 DAE, the control treatment showed the highest foliar consumption and the lowest mortality of caterpillars, while the other treatments applied in soybean seeds had low defoliation intensity and $100 \%$ mortality of caterpillars, without differing among themselves (Table 4). In the last evaluation of foliar consumption and mortality of caterpillars carried out with soybean plants from Itiquira (35 DAE), the treatment fipronil (50 g i.a.) presented the highest leaf consumption and the lowest mortality of caterpillars, being these equivalent to the 
control, while the cyantraniliprole + thiamethoxam $(60+70$ g i.a. $)$ mixture had the lowest leaf consumption (Table 3).

Table 2. Percentage of leaf area consumed (LAC) and mortality (M) of Chrysodeixis includens caterpillars, evaluated in the laboratory at 7, 14, 21, 28 and 35 days after plant emergence (DAE) in different treatments applied to soybean seeds in the municipality of Itiquira/MT

\begin{tabular}{|c|c|c|c|c|c|c|c|c|c|c|}
\hline \multirow{2}{*}{ Treatments (g a.i./ha) } & \multicolumn{2}{|c|}{$7 \mathrm{DAE}$} & \multicolumn{2}{|c|}{14 DAE } & \multicolumn{2}{|c|}{$21 \mathrm{DAE}$} & \multicolumn{2}{|c|}{$28 \mathrm{DAE}$} & \multicolumn{2}{|c|}{$35 \mathrm{DAE}$} \\
\hline & LAC (\%) & $\mathrm{M}(\%)$ & LAC (\%) & M (\%) & LAC (\%) & M (\%) & LAC (\%) & M (\%) & LAC $(\%)$ & M (\%) \\
\hline $\begin{array}{l}\text { Control } \\
\text { (without insecticide) }\end{array}$ & $100.0 \pm$ & 0.0 & $7 \pm 7.1 \mathrm{abc}$ & $28.1 \pm 6.3 b c$ & $.9 \pm 5.7 \mathrm{ab}$ & $15.6 \pm 6.3 b c$ & $93.8 \pm 6.5 \mathrm{a}$ & $6.3 \pm 7.2 \mathrm{a}$ & $91.1 \pm 11.4 \mathrm{a}$ & $6.3 \pm 7.2 \mathrm{a}$ \\
\hline Chlorantraniliprole (62.5) & $52.02 \pm 21.6 \mathrm{ab}$ & $62.5 \pm 32.3 \mathrm{ab}$ & $51.5 \pm 13.7 \mathrm{c}$ & $56.3 \pm 12.5 \mathrm{a}$ & $62.8 \pm 7.7 \mathrm{abc}$ & $43.8 \pm 12.5 \mathrm{ab}$ & $92.2 \pm 7.9 \mathrm{a}$ & $6.3 \pm 12.5 \mathrm{a}$ & $88.4 \pm 13.4 \mathrm{a}$ & $12.5 \pm 14.4 \mathrm{a}$ \\
\hline $\begin{array}{l}\text { Tiodicarbe }+ \\
\text { imidacloprido }(75+25)\end{array}$ & $72.5 \pm 31.7 \mathrm{ab}$ & $31.3 \pm 37.5 \mathrm{ab}$ & $80.8 \pm 18.0 \mathrm{ab}$ & $12.5 \pm 25.0 \mathrm{bc}$ & $93.8 \pm 12.5 \mathrm{a}$ & $6.3 \pm 12.5 \mathrm{c}$ & $94.1 \pm 11.9 \mathrm{a}$ & $6.3 \pm 12.5 \mathrm{a}$ & $100.0 \pm 0.0 \mathrm{a}$ & $0.0 \pm 0.0 \mathrm{a}$ \\
\hline Fipronil (50) & $69.7 \pm 21.3 \mathrm{ab}$ & $31.3 \pm 23.9 \mathrm{ab}$ & $91.9 \pm 4.6 \mathrm{a}$ & $0.0 \pm 0.0 \mathrm{c}$ & $61.6 \pm 16.5 b c$ & $37.5 \pm 14.4 \mathrm{ab}$ & $89.7 \pm 12.2 \mathrm{a}$ & $12.5 \pm 14.4 \mathrm{a}$ & $89.4 \pm 12.3 \mathrm{a}$ & $12.5 \pm 14.4 \mathrm{a}$ \\
\hline Thiamethoxam (70) & $81.6 \pm 22.0 \mathrm{a}$ & $25.0 \pm 28.9 \mathrm{ab}$ & $69.1 \pm 22.0 \mathrm{abc}$ & $37.5 \pm 25.0 \mathrm{ab}$ & $71.9 \pm 22.7 \mathrm{abc}$ & $25.0 \pm 20.4 \mathrm{abc}$ & $75.0 \pm 29.8 \mathrm{a}$ & $31.3 \pm 31.5 \mathrm{a}$ & $93.4 \pm 13.1 \mathrm{a}$ & $12.5 \pm 25.0 \mathrm{a}$ \\
\hline $\begin{array}{l}\text { Cyantraniliprole }+ \\
\text { thiamethoxam }(60+70)\end{array}$ & $25.9 \pm 16.1 b$ & $81.3 \pm 23.9 \mathrm{a}$ & $54.7 \pm 17.9 \mathrm{bc}$ & $56.3 \pm 23.9 \mathrm{a}$ & $50.0 \pm 4.3 \mathrm{c}$ & $50.0 \pm 0.0 \mathrm{a}$ & $86.6 \pm 12.9 \mathrm{a}$ & $18.8 \pm 23.9 \mathrm{a}$ & $85.9 \pm 9.8 \mathrm{a}$ & $25.0 \pm 20.4 \mathrm{a}$ \\
\hline CV $(\%)$ & 31.1 & 71.3 & 17.5 & 41 & 19.7 & 45.6 & 18.2 & 149.7 & 12.3 & 138.4 \\
\hline
\end{tabular}

Note. Averages \pm Standard Error (SE) followed by the same letter in the column did not differ statistically from each other by the Tukey test $(p<0.05)$.

Table 3. Percentage of leaf area consumed (LAC) and mortality (M) of Chrysodeixis includens caterpillars, evaluated in the laboratory at 7, 14, 21, 28 and 35 days after plant emergence (DAE) in different treatments applied to soybean seeds in the municipality of Juscimeira/MT

\begin{tabular}{|c|c|c|c|c|c|c|c|c|c|c|}
\hline \multirow{2}{*}{ Treatments (g a.i./ha) } & \multicolumn{2}{|c|}{$7 \mathrm{DAE}$} & \multicolumn{2}{|c|}{$14 \mathrm{DAE}$} & \multicolumn{2}{|c|}{$21 \mathrm{DAE}$} & \multicolumn{2}{|c|}{$28 \mathrm{DAE}$} & \multicolumn{2}{|c|}{$35 \mathrm{DAE}$} \\
\hline & LAC $(\%)$ & M (\%) & LAC (\%) & $\mathrm{M}(\%)$ & $\operatorname{LAC}(\%)$ & $\mathrm{M}(\%)$ & LAC (\%) & $\mathrm{M}(\%)$ & $\operatorname{LAC}(\%)$ & $\mathrm{M}(\%)$ \\
\hline $\begin{array}{l}\text { Control } \\
\text { (without insecticide) }\end{array}$ & $84.6 \pm 18.5 \mathrm{a}$ & $15.6 \pm 18.8 \mathrm{a}$ & $97.0 \pm 5.9 \mathrm{a}$ & $3.1 \pm 6.3 \mathrm{a}$ & $84.4 \pm 6.3 \mathrm{a}$ & $15.6 \pm 6.3 \mathrm{a}$ & $85.3 \pm 11.3 \mathrm{a}$ & $15.6 \pm 12.0 \mathrm{a}$ & $15.9 \pm 1.9 \mathrm{a}$ & $9.4 \pm 6.3 \mathrm{a}$ \\
\hline Chlorantraniliprole (62.5) & $67.5 \pm 23.6 \mathrm{a}$ & $31.3 \pm 23.9 \mathrm{a}$ & $80.6 \pm 13.0 \mathrm{a}$ & $18.8 \pm 12.5 \mathrm{a}$ & $94.7 \pm 10.6 \mathrm{a}$ & $6.3 \pm 12.5 \mathrm{a}$ & $100.0 \pm 0.0 \mathrm{a}$ & $0.0 \pm 0.0 \mathrm{a}$ & $19.4 \pm 1.6 \mathrm{a}$ & $0.0 \pm 0.0 \mathrm{a}$ \\
\hline $\begin{array}{l}\text { Tiodicarbe }+ \\
\text { imidacloprido }(75+25)\end{array}$ & $82.2 \pm 11.9 \mathrm{a}$ & $18.8 \pm 12.5 \mathrm{a}$ & $81.3 \pm 12.5 \mathrm{a}$ & $25.0 \pm 20.4 \mathrm{a}$ & $93.8 \pm 12.5 \mathrm{a}$ & $6.3 \pm 12.5 \mathrm{a}$ & $94.7 \pm 10.6 \mathrm{a}$ & $6.3 \pm 12.5 \mathrm{a}$ & $17.5 \pm 2.3 \mathrm{a}$ & $0.0 \pm 0.0 \mathrm{a}$ \\
\hline Fipronil (50) & $88.1 \pm 13.8 \mathrm{a}$ & $12.5 \pm 14.4 \mathrm{a}$ & $87.5 \pm 14.4 \mathrm{a}$ & $12.5 \pm 14.4 \mathrm{a}$ & $100.0 \pm 0.0 \mathrm{a}$ & $0.0 \pm 0.0 \mathrm{a}$ & $89.1 \pm 12.6 \mathrm{a}$ & $12.5 \pm 14.4 \mathrm{a}$ & $14.1 \pm 1.9 \mathrm{a}$ & $6.3 \pm 12.5 \mathrm{a}$ \\
\hline Thiamethoxam (70) & $83.1 \pm 11.3 \mathrm{a}$ & $18.8 \pm 12.5 \mathrm{a}$ & $100.0 \pm 0.0 \mathrm{a}$ & $6.3 \pm 12.5 \mathrm{a}$ & $94.1 \pm 11.9 \mathrm{a}$ & $6.3 \pm 12.5 \mathrm{a}$ & $100.0 \pm 0.0 \mathrm{a}$ & $0.0 \pm 0.0 \mathrm{a}$ & $16.3 \pm 5.1 \mathrm{a}$ & $0.0 \pm 0.0 \mathrm{a}$ \\
\hline $\begin{array}{l}\text { Cyantraniliprole }+ \\
\text { thiamethoxam }(60+70)\end{array}$ & $77.5 \pm 15.5 \mathrm{a}$ & $25.0 \pm 20.4 \mathrm{a}$ & $94.4 \pm 11.3 \mathrm{a}$ & $6.3 \pm 12.5 \mathrm{a}$ & $93.8 \pm 12.5 \mathrm{a}$ & $6.3 \pm 12.5 \mathrm{a}$ & $93.8 \pm 12.5 \mathrm{a}$ & $6.3 \pm 12.5 \mathrm{a}$ & $16.6 \pm 3.0 \mathrm{a}$ & $0.0 \pm 0.0 \mathrm{a}$ \\
\hline $\mathrm{CV}(\%)$ & 22.5 & 92.1 & 12.8 & 125.2 & 11.1 & 160.1 & 10.1 & 162.5 & 17.3 & 213.1 \\
\hline
\end{tabular}

Note. Averages \pm Standard Error (SE) followed by the same letter in the column did not differ statistically from each other by the Tukey test $(p<0.05)$.

Table 4. Percentage of leaf area consumed (LAC) and mortality (M) of Anticarsia gemmatalis caterpillars, evaluated in the laboratory at 14, 21, 28 and 35 days after plant emergence (DAE) in the different treatments applied in the soybean seeds of the municipality of Itiquira/MT

\begin{tabular}{|c|c|c|c|c|c|c|c|c|}
\hline \multirow{2}{*}{ Treatments (g a.i./ha) } & \multicolumn{2}{|c|}{$14 \mathrm{DAE}$} & \multicolumn{2}{|c|}{$21 \mathrm{DAE}$} & \multicolumn{2}{|c|}{$28 \mathrm{DAE}$} & \multicolumn{2}{|c|}{$35 \mathrm{DAE}$} \\
\hline & LAC $(\%)$ & $\mathrm{M}(\%)$ & LAC $(\%)$ & $\mathrm{M}(\%)$ & LAC $(\%)$ & $\mathrm{M}(\%)$ & LAC $(\%)$ & $\mathrm{M}(\%)$ \\
\hline $\begin{array}{l}\text { Control } \\
\text { (without insecticide) }\end{array}$ & $7.8 \pm 4.3 \mathrm{a}$ & $0.0 \pm 0.0 \mathrm{~b}$ & $37.5 \pm 19.6 \mathrm{a}$ & $87.5 \pm 14.4 b$ & $65.0 \pm 13.0 \mathrm{a}$ & $37.5 \pm 14.4 b$ & $37.2 \pm 21.6 \mathrm{ab}$ & $68.8 \pm 23.9 \mathrm{ab}$ \\
\hline Chlorantraniliprole (62.5) & $5.0 \pm 0.0 \mathrm{a}$ & $100.0 \pm 0.0 \mathrm{a}$ & $3.4 \pm 0.6 b$ & $100.0 \pm 0.0 \mathrm{a}$ & $4.4 \pm 0.7 b$ & $100.0 \pm 0.0 \mathrm{a}$ & $7.5 \pm 2.3 \mathrm{bc}$ & $100.0 \pm 0.0 \mathrm{a}$ \\
\hline $\begin{array}{l}\text { Tiodicarbe }+ \\
\text { imidacloprido }(75+25)\end{array}$ & $9.7 \pm 6.5 \mathrm{a}$ & $0.0 \pm 0.0 \mathrm{~b}$ & $34.7 \pm 13.4 \mathrm{a}$ & $93.8 \pm 12.5 \mathrm{a}$ & $5.0 \pm 0.0 \mathrm{~b}$ & $100.0 \pm 0.0 \mathrm{a}$ & $13.1 \pm 12.1 b c$ & $93.8 \pm 12.5 \mathrm{ab}$ \\
\hline Fipronil (50) & $6.6 \pm 1.2 \mathrm{a}$ & $100.0 \pm 0.0 \mathrm{a}$ & $17.8 \pm 11.0 \mathrm{ab}$ & $93.8 \pm 12.5 \mathrm{a}$ & $5.0 \pm 0.0 \mathrm{~b}$ & $100.0 \pm 0.0 \mathrm{a}$ & $47.2 \pm 20.8 \mathrm{a}$ & $62.5 \pm 25.0 \mathrm{~b}$ \\
\hline Thiamethoxam (70) & $9.4 \pm 5.4 \mathrm{a}$ & $0.0 \pm 0.0 \mathrm{~b}$ & $25.9 \pm 5.0 \mathrm{ab}$ & $100.00 \pm 0.0 \mathrm{a}$ & $5.0 \pm 0.0 \mathrm{~b}$ & $100.0 \pm 0.0 \mathrm{a}$ & $10.6 \pm 3.6 b c$ & $100.0 \pm 0.0 \mathrm{a}$ \\
\hline $\begin{array}{l}\text { Cyantraniliprole }+ \\
\text { thiamethoxam }(60+70)\end{array}$ & $5.0 \pm 0.0 \mathrm{a}$ & $100.0 \pm 0.0 \mathrm{a}$ & $5.0 \pm 1.0 \mathrm{~b}$ & $100.00 \pm 0.0 \mathrm{a}$ & $5.0 \pm 0.0 \mathrm{~b}$ & $100.0 \pm 0.0 \mathrm{a}$ & $5.9 \pm 3.1 \mathrm{c}$ & $100.0 \pm 0.0 \mathrm{a}$ \\
\hline $\mathrm{CV}(\%)$ & 55.6 & 0.6 & 51.8 & 9.9 & 35.4 & 6.5 & 66.4 & 17.3 \\
\hline
\end{tabular}

Note. Averages \pm Standard Error (SE) followed by the same letter in the column did not differ statistically from each other by the Tukey test $(p<0.05)$. 
In the test conducted with soybean plants from the Municipality of Juscimeira with A. gemmatalis, it was verified that the caterpillars that fed $7 \mathrm{DAE}$, presented reduced leaf consumption in the treatments chlorantraniliprole $(62.50 \mathrm{~g}$ a.i.), thiamethoxam $(70 \mathrm{~g}$ a.i. $)$ and with the mixture of cyantraniliprole + thiamethoxam ( $62.50 \mathrm{~g}$ a.i.), when compared to the control. However, all chemical treatments showed relatively high mortality of A. gemmatalis caterpillars, surpassing the mortality observed in the control (Table 5).

At 14 DAE, all chemical treatments showed a relatively lower defoliation of soybeans compared to the control (Table 5), with emphasis on the treatments chlorantraniliprole (62.5 g a.i.) and cyantraniliprole + thiamethoxam $(60+70 \mathrm{~g}$ a.i.), however the highest caterpillar mortalities were also observed with chlorantraniliprole $(62.5 \mathrm{~g}$ a.i.) and the mixture of cyantraniliprole + thiamethoxam $(60+70 \mathrm{~g}$ a.i. $)$. At $21 \mathrm{DAE}$, there was no treatment effect on the defoliation caused by A. gemmatalis caterpillars, however, the higher mortality was presented with the treatment cyantraniliprole + thiamethoxam (62.50 g a.i.), which surpassed the mortality verified in the control and the thiamethoxam treatment (70 g a.i.) (Table 5). In the evaluations performed at 28 and $35 \mathrm{DAE}$, no significant treatment effect was observed for both leaf consumption and caterpillars mortality of $A$. gemmatalis (Table 5).

\section{Discussion}

It is known that almost all the soybean seeds currently marketed in Brazil present some type of chemical treatment aimed at controlling especially pests or diseases (Pereira et al., 2011). The use of insecticides and fungicides, applied to the seeds, can significantly improve the soybean stand as well as the grain yield of the crop (Rossman et al., 2018; Milosavljević et al., 2019). In the case of insecticides, the use of active ingredients isolated or mixed in the seed treatment for pest control is an ancient practice (Munkvold et al., 2006).

Some of the active ingredients used in the seeds, such as the neonicotinoids (thiamethoxam, imidacloprid, clothianidin), provide an improvement in the agronomic characteristics of some crops, resulting in increased productivity (Jeschke et al., 2011; Szczepaniec et al., 2013; Afifi et al., 2014; Alford \& Krupke, 2017). Neonicotinoids are persistent insecticides and provide long-term protection for seeds and seedlings of different species, and can control pests that are difficult to manage right after planting (Cherry et al., 2017; Milosavljević et al., 2019). Neonicotinoids are toxins that act on the acetylcholine receptors (nAChR) of insects, and as a result cause collapse due to a rupture of the nerve signals, leading the insect to death. These insecticides when applied to seeds provide precise targeting through systemic action in the plant, which favors the agroecossystem, as they can reduce the number of sprays in the aerial part of the plants, as well as the risk of deleterious effects in non-target organisms, such as pollinators and the complex of natural enemies (Bonmatin et al., 2015; Douglas \& Tooker, 2015; Furlan \& Kreutzweiser, 2015).

Regarding the results obtained at the two sites where the experiments were conducted (Juscimeira and Itiquira) one can observe a highlight for the insecticides of the diamidas group. This group acts as an activator of the rianodine receptors, and during the mode of action in lepidopteran larvae causes deregulated release of internal calcium in the cell is verified, this causes rapid cessation of feeding, lethargy, partial paralysis and consequently the death of the insect (Cordova et al., 2006; Lahm et al., 2007). These possible effects corroborate with the results obtained for the insecticides cyantraniliprole and chlorantraniliprole, for which during almost all the evaluations in which caterpillars were fed with leaves of soybean whose seeds had been treated with these products presented a smaller consumption of the leaf area and a greater mortality of caterpillars. Regarding leaf consumption and, consequently, damage caused by defoliating caterpillars in soybean cultivation, there is a constant concern, since only one caterpillar during its larval phase, can have leaf consumption of 85 to $150 \mathrm{~cm}^{2}$ of which could compromise the development of the crop (Bueno et al., 2011).

The effect of the insecticides cyantraniliprole and chlorantraniliprole when applied in treatment of soybean seeds against $A$. gemmatalis caterpillars has been reported by Rodrigues et al. (2014). Thrash et al. (2013) found that Spodoptera frugiperda (Smith) (Lepidoptera: Noctuidae) caterpillars when fed with soybean leaflets, where the seeds received treatment with chlorantraniliprole and cyantraniliprole also had a high larval mortality. When submitting caterpillars of Mythimna unipuncta (Haworth) (Lepidoptera: Noctuidae) fed with corn leaves in which the seeds were treated with chlorantraniliprole, alone or in combination, the larval mortality of this species occurred earlier, compared to the treatment where there was no application of this insecticide (Carscallen et al., 2019). Suzana et al. (2017) also verified that the insecticides cyantraniliprole and chlorantraniliprole, used in the proportion of 60 and $62.5 \mathrm{~g}$ a.i. $/ 100 \mathrm{~kg}$ of seeds, demonstrated potential for the control of $\mathrm{H}$. armigera caterpillars even 13 days after the emergence of the plants of soybean. 
Table 5. Percentage of leaf area consumed (LAC) and mortality (M) of Anticarsia gemmatalis caterpillars, evaluated in the laboratory at 7, 14, 21, 28 and 35 days after plant emergence (DAE) in the different treatments applied in the soybean seeds of the municipality of Juscimeira/MT

\begin{tabular}{|c|c|c|c|c|c|c|c|c|c|c|}
\hline \multirow{2}{*}{ Treatments (g a.i./ha) } & \multicolumn{2}{|c|}{$7 \mathrm{DAE}$} & \multicolumn{2}{|c|}{$14 \mathrm{DAE}$} & \multicolumn{2}{|c|}{$21 \mathrm{DAE}$} & \multicolumn{2}{|c|}{$28 \mathrm{DAE}$} & \multicolumn{2}{|c|}{$35 \mathrm{DAE}$} \\
\hline & $\mathrm{LAC}(\%)$ & M (\%) & $\mathrm{LAC}(\%)$ & M (\%) & $\mathrm{LAC}(\%)$ & $\mathrm{M}(\%)$ & $\mathrm{LAC}(\%)$ & M (\%) & $\mathrm{LAC}(\%)$ & $\mathrm{M}(\%)$ \\
\hline $\begin{array}{l}\text { Control } \\
\text { (without insecticide) }\end{array}$ & $46.2 \pm 6.9 \mathrm{a}$ & $37.5 \pm 14.4 \mathrm{~b}$ & $91.6 \pm 5.9 \mathrm{a}$ & $6.3 \pm 7.2 \mathrm{~b}$ & $59.2 \pm 5.2 \mathrm{a}$ & $46.9 \pm 6.3 b$ & $82.5 \pm 10.3 \mathrm{a}$ & $12.5 \pm 10.2 \mathrm{a}$ & $91.7 \pm 5.6 \mathrm{a}$ & $9.4 \pm 6.3 \mathrm{a}$ \\
\hline Chlorantraniliprole (62.5) & $1.9 \pm 0.7 \mathrm{c}$ & $100.0 \pm 0.0 \mathrm{a}$ & $5.3 \pm 1.6 \mathrm{~d}$ & $87.5 \pm 14.4 \mathrm{a}$ & $38.8 \pm 18.2 \mathrm{a}$ & $75.0 \pm 20.4 \mathrm{ab}$ & $78.8 \pm 19.9 \mathrm{a}$ & $18.8 \pm 23.9 \mathrm{a}$ & $100.0 \pm 0.0 \mathrm{a}$ & $0.0 \pm 0.0 \mathrm{a}$ \\
\hline $\begin{array}{l}\text { Tiodicarbe }+ \\
\text { imidacloprido }(75+25)\end{array}$ & $24.4 \pm 10.2 b$ & $81.3 \pm 12.5 \mathrm{a}$ & $22.8 \pm 1.6 \mathrm{bc}$ & $0.0 \pm 0.0 \mathrm{~b}$ & $38.1 \pm 19.5 \mathrm{a}$ & $75.0 \pm 28.9 \mathrm{ab}$ & $87.5 \pm 14.4 \mathrm{a}$ & $12.5 \pm 14.4 \mathrm{a}$ & $94.1 \pm 11.9 \mathrm{a}$ & $6.3 \pm 12.5 \mathrm{a}$ \\
\hline Fipronil (50) & $11.6 \pm 3.6 \mathrm{bc}$ & $100.0 \pm 0.0 \mathrm{a}$ & $13.4 \pm 5.0 \mathrm{~cd}$ & $31.3 \pm 23.9 \mathrm{~b}$ & $56.6 \pm 21.9 \mathrm{a}$ & $56.3 \pm 23.9 \mathrm{ab}$ & $60.6 \pm 17.5 \mathrm{a}$ & $18.8 \pm 12.5 \mathrm{a}$ & $81.6 \pm 23.4 \mathrm{a}$ & $18.8 \pm 23.9 \mathrm{a}$ \\
\hline Thiamethoxam (70) & $6.3 \pm 10.1 \mathrm{c}$ & $93.8 \pm 12.5 \mathrm{a}$ & $18.8 \pm 6.2 \mathrm{bc}$ & $6.3 \pm 12.5 b$ & $62.5 \pm 19.6 \mathrm{a}$ & $43.8 \pm 23.9 b$ & $73.4 \pm 15.4 \mathrm{a}$ & $18.8 \pm 12.5 \mathrm{a}$ & $93.8 \pm 12.5 \mathrm{a}$ & $6.3 \pm 12.5 \mathrm{a}$ \\
\hline $\begin{array}{l}\text { Cyantraniliprole }+ \\
\text { thiamethoxam }(60+70)\end{array}$ & $0.3 \pm 0.7 \mathrm{c}$ & $100.0 \pm 0.0 \mathrm{a}$ & $6.9 \pm 2.2 \mathrm{~d}$ & $75.0 \pm 0.0 \mathrm{a}$ & $29.5 \pm 12.2 \mathrm{a}$ & $100.0 \pm 0.0 \mathrm{a}$ & $100.0 \pm 0.0 \mathrm{a}$ & $0.0 \pm 0.0 \mathrm{a}$ & $100.0 \pm 0.0 \mathrm{a}$ & $0.0 \pm 0.0 \mathrm{a}$ \\
\hline $\mathrm{CV}(\%)$ & 40.6 & 9.7 & 17.4 & 40 & 34.6 & 30.5 & 16.9 & 101.5 & 14.3 & 173.4 \\
\hline
\end{tabular}

Note. Averages \pm Standard Error (SE) followed by the same letter in the column did not differ statistically from each other by the Tukey test $(p<0.05)$.

It is worth noting that chlorantraniliprole has the same toxic action for insects when compared to fast acting insecticides, such as carbamates and pyrethroids, for example, but with the benefit of having a more favorable toxicological and ecotoxicological profile (Hannig et al., 2009). Also, in tests of caterpillar mortality, it has been verified that the insecticide cyantraniliprole demonstrates that its oral toxicity is superior to its toxicity by contact, thus evidencing that the ingestion of this active ingredient is important for the control of these insects, which emphasizes and their importance in seed treatment (Bird, 2016; Dong et al., 2016; Suzana et al., 2017). However, this group of diamidas deserves attention, since studies carried out with different populations of caterpillars, shortly after their introduction in the US market, showed a high risk for the development resistance of C. includens to this mode of action (Owen et al., 2013).

The inability of the insecticide fipronil to prevent leaf consumption of $A$. gemmatalis and $C$. includens in this study indicates a limitation of the use of this active principle in the dose tested when applied to soybean seeds. However, its toxic effect through the inhibition of neuronal receptors in lepidopterans has been observed (Colliot et al., 1992; Carneiro et al., 2014)

When analyzing the effect of soil textures in the two environments in which the tests were conducted, there is generally a lower percentage of leaf area consumed and higher mortality of both species of caterpillars for soybean cultivated in Itiquira compared to soybean cultivated in Juscimeira, especially for the treatments chlorantraniliprole (62.5 g a.i.) and cyantraniliprole + thiamethoxam $(60+70 \mathrm{~g}$ a.i.). The soil of Itiquira is characterized by a sandy texture (Table 1), which may have favored a greater availability of the insecticides in the soil solution and, consequently, a better absorption by the soybean plants and thus providing a higher mortality and lower leaf consumption of caterpillars. Felsot and Lew (1989), when studying soil types, solubility in water and organic matter for carbofuran and terbufos, concluded that all these factors affect the toxicity of an insecticide, being able to decrease or increase their efficiency, being the best results observed for low solubility products. Brustolin (2012) tested different soil types in relation to damage and control of Dichelops melacanthus (Hemiptera: Pentatomidae). A sandy soil with a lower concentration of organic matter and clay present low adsorption, which allows a greater absorption of the molecules of the products by the plants, as probably occurred in this work for the soil of Itiquira. The termite species Campotermes formosanus (Isoptera: Rhinotermitidae) can rapidly acquire the lethal dose of chlorantraniliprole in treated sandy soil, but this effect cannot occur when the insects are in soils with high organic matter content (Gautam \& Henderson, 2011). When the insecticides deltamethrin and cypermethrin were applied in soils with high clay content, there was a reduction of their action for the control of $C$. formosanus, as well as the bioactivity of chlorpyrifos and imidacloprid was also compromised, probably due to the lower availability of these products in the soil solution (Henderson et al., 1998). Spomer et al. (2009) also verified that soils with high organic matter content reduced the availability of the insecticides indoxacarb and chlorantraniliprole to control the termite Reticulitermes flavipes (Isoptera: Rhinotermitidae) when compared to soils with low organic matter content. A similar fact occurred probably in this work for the soil of Juscimeira that is clayey and has a higher content of organic matter (Table 1). In that soil the effects on leaf consumption and mortality of caterpillars were low or null, especially for specie $C$. includens (Table 3). 
Another factor that could have affected the absorption of insecticides in these two environments in which this study was conducted was probably related to the availability of water in the soil, as a function of the degree of precipitation that occurred in the two localities where the study was conducted. It was verified that in the São Miguel Farm of the Municipality of Itiquira the intensity of precipitation was much greater than the one observed in the Mirandópolis Farm of the Municipality Juscimeira (Figure 1). This greater availability of water in the soil of Itiquira may have favored the absorption by the plants of the products applied in the seeds and, consequently, have had a more significant effect on foliar consumption and mortality of the caterpillars when compared to the soil of Juscineira. The species Acheta pennsylvanicus (Burmeister) (Orthoptera: Gryllidae) had its effective control from insecticides applied to soils considered wet in comparison to dry soils (Harris, 1966).

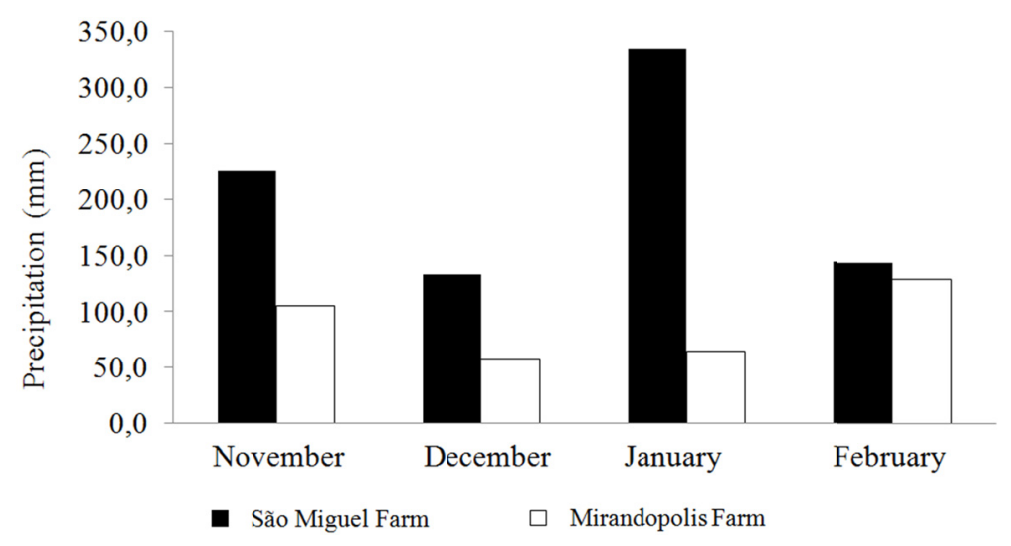

Figure 1. Monthly precipitation (mm) observed from November 2015 to February 2016 in the areas of the São Miguel Farm (Itiquira/MT) and Mirandópolis Farm (Juscimeira/MT)

In general, the control of the A. gemmatalis and C. includens caterpillars in this study were higher in the early stages of the crop, when the soybean seeds were treated with different insecticides. Thus, the use of this control technique may be an alternative to reduce the initial attack of caterpillars in soybean crop, especially when associated with other management tactics (Ávila \& Santos, 2018). In addition, seed treatment usually uses a low dose of active ingredients per hectare and is therefore a selective control tactic for most of the natural enemies and beneficial insects associated with this crop (Santos et al., 2006; Cunha et al., 2015).

\section{Acknowledgements}

The authors are very grateful for the support of the MT Foundation, as well as its collaborators and Embrapa Agropecuária Oeste (Embrapa West Agriculture), and the Coordenação de Aperfeiçoamento de Pessoal de Nível Superior (CAPES).

\section{References}

Afifi, M., Lee, E., Lukens, L., \& Swanton, C. (2014). Thiamethoxam as a seed treatment alters the physiological response of maize (Zea mays) seedlings to neighboring weeds. Pest Manag. Sci., 71, 1-10. https://doi.org/ $10.1002 / \mathrm{ps} .3789$

Alford, A., \& Krupke, C. H. (2017). Translocation of the neonicotinoid seed treatment clothianidin in maize. PLoS One, 12, e0173836. https://doi.org/10.1371/journal.pone.0173836

Ávila, C. J., \& Schlick-Souza, E. C. (2015). Ocorrência de Insetos-Pragas e de seus Predadores em Sistemas Integrados de Produção de Soja (Documentos 137, p. 31). Embrapa Agropecuária Oeste, Brazil.

Balardin, R. S., Silva, F. D. L., Debona, D., Corte, G. D., Favera, D. D., \& Tormen, N. D. (2011). Tratamento de sementes com fungicidas e inseticidas como redutores dos efeitos do estresse hídrico em plantas de soja. Ciênc Rural, 41, 1120-1126. https://doi.org/10.1590/S0103-84782011000700002

Bernardi, O., Malvestiti, G. S., Dourado, P. M., Oliveira, W. S., Martinelli, S., Berger, G. U., ... Omoto, C. (2012). Assessment of the high dose concept and level of control provided by MON $87701 \times$ MON 89788 soybean against Anticarsia gemmatalis and Pseudoplusia includens (Lepidoptera: Noctuidae) in Brazil. Pest Manag. Sci., 68, 1083-1091. https://doi.org/10.1002/ps.3271 
Bird, L. J. (2016). Susceptibility of Helicoverpa armigera (Lepidoptera: Noctuidae) to cyantraniliprole determined from topical and ingestion bioassays. J. Econ. Entomol., 109, 1350-1356. https://doi.org/ 10.1093/jee/tow027

Bonmatin, J. M., Giorio, C., Girolami, V., Goulson, D., Kreutzweiser, D. P., Krupke, C., ... Tapparo, A. (2015). Environmental fate and exposure; neonicotinoids and fipronil. Envir. Sci. Pol. Res., 22, 35-67. https://doi.org/10.1007/s11356-014-3332-7

Bortolotto, O. C., Pomari-Fernandes, A., Bueno, R. C. O. F., Bueno, A. F., Kruz, Y. K. S., Queiroz, A. P., ... Ferreira, R. B. (2015). The use of soybean integrated pest management in Brazil: A review. Agron. Sci. Biotec., 1, 25-32.

Brustolin, C., Neves, P. M. O. J., Bianco, R., \& Bortolotto, O. C. (2017). Tratamento de sementes de milho para controlar Dichelops melacanthus em diferentes tipos de solo. Rev. Bras. Milho Sorgo, 16, 13-21. https://doi.org/10.18512/19806477/rbms.v16n1p13-21

Bueno, R. C. O. F., Bueno, A. F., Moscardi, F., Parra, J. R. P., \& Hoffmann-Campo, C. B. (2011). Lepidopteran larvae consumption of soybean foliage: Basis for developing multiple species economic thresholds for pest management decisions. Pest Manag. Sci., 67, 170-174. https://doi.org/10.1002/ps.2047

Camargo, C., Snow, D. D., Onanong, S., Hunt, T. E., \& Siegfried, B. D. (2019). Residues of thiamethoxam and mefenoxam in vegetative and floral tissue of soybean at the early reproductive stage resulting from seed treatments. Crop Prot., 119, 134-140. https://doi.org/10.1016/j.cropro.2019.01.019

Carneiro, E., Silva, L. B., Maggioni, K., Santos, V. B., Rodrigues, T. F., Reis, S. S., \& Pavan, B. E. (2014). Evaluation of insecticides targeting control of Helicoverpa armigera (Hubner) (Lepidoptera: Noctuidae). Amer. J. Plant Sci., 5, 2823-2828. https://doi.org/10.4236/ajps.2014.518298

Carscallen, G. E., Kher, S. V., \& Evenden, M. L. (2019). Efficacy of Chlorantraniliprole Seed Treatments Against Armyworm (Mythimna unipuncta [Lepidoptera: Noctuidae]) Larvae on Corn (Zea mays). J. Econ. Entomol., 112, 188-95. https://doi.org/10.1093/jee/toy338

Castro, G. S. A., Bogiani, L. C., Silva, M. G., Gazola, E., \& Rosolem, C. A. (2008). Soybean seed treatment with insecticides and biostimulant. Pesq. Agropec. Bras., 4, 1311-1318.

Cattelan, A. J., \& Dall'Agnol, A. (2018). The rapid soybean growth in Brazil. OCL, 25, D102. https://doi.org/10.1051/ocl/2017058

Chang, H. X., \& Hartman, G. L. (2017). Characterization of Insect Resistance Loci in the USDA Soybean Germplasm Collection Using Genome-Wide Association Studies. Front. Plant Sci., 8, 664-670. https://doi.org/10.3389/fpls.2017.00670

Cherry, R., Taylor, J., Sherrod, D., \& Karounos, M. (2017). Corn seed treatments for control of the corn wireworm (Coleoptera: Elateridae). J. Entomol. Sci., 52, 161-168. https://doi.org/10.18474/JES16-20.1

Colliot, F., Kukorowki, K. A., Hawkins, D. W., \& Roberts, D. A. (1992). Fipronil: A new soil and foliar broad spectrum insecticide. Proceedings of Brighton Crop Protection Conference, Pests and Diseases (pp. 29-34).

Cordova, D., Benner, E. A., Sacher, M. D., Rauh, J. J., Sopa, J. S., Lahm, G. P., ... Tao, Y. (2006). Anthranilic diamides: A new class of insecticides with a novel mode of action, ryanodine receptor activation. Pest Biochem. Physiol., 84, 196-214. https://doi.org/10.1016/j.pestbp.2005.07.005

Cox, W. J., \& Cherney, J. H. (2011). Location, variety, and seeding rate interactions with soybean seed-applied insecticide/fungicides. Agron. J., 103, 1366-1371. https://doi.org/10.2134/agronj2011.0129

Cunha, R. P., Corrêa, M. F., Schuch, L. O. B., Oliveira, R. C., Junior, J. S. A., Silva, J. D. G., \& Almeida, T. L. (2015). Diferentes tratamentos de sementes sobre o desenvolvimento de plantas de soja. Ciênc. Rural, 45, 1761-1767. https://doi.org/10.1590/0103-8478cr20140742

Dong, J., Wang, K., Li, Y., \& Wang, S. (2017). Lethal and sublethal effects of cyantraniliprole on Helicoverpa assulta (Lepidoptera: Noctuidae). Pest Biochem. Physiol., 136, 58-63. https://doi.org/10.1016/j.pesybp. 2016.08.003

Douglas, M. R., \& Tooker, J. F. (2015). Large-scale deployment of seed treatments has driven rapid increase in use of neonicotinoid insecticides and preemptive pest management in U.S. field crops. Envir. Sci. Tec., 49, 5088-5097. https://doi.org/10.1021/es506141g 
Felsot, A. S., \& Lew, A. (1989). Factors affecting bioactivities of soil insecticides: Relationships among uptake, desorption, and solubility of carbofuran and terbufos. J. Econ. Entomol., 82, 389-394. https://doi.org/ $10.1093 /$ jee/82.2.389

Furlan, L., \& Kreutzweiser, D. (2015). Alternatives to neonicotinoid insecticides for pest control: Case studies in agriculture and forestry. Environ. Sci. Pollut. Res., 22, 135-147. https://doi.org/10.1007/s11356-014-3628-7

Gautam, B. K., \& Henderson, G. (2011). Effect of sand moisture level on food consumption and distribution of Formosan subterranean termites (Isoptera: Rhinotermitidae) with different soldier proportions. J. Econ. Sci., 46, 1-13. https://doi.org/10.18474/0749-8004-46.1.1

Hannig, G. T., Ziegler, M., \& Marçon, P. G. (2009). Feeding cessation effects of chlorantraniliprole, a new anthranilic diamide insecticide, in comparison with several insecticides in distinct chemical classes and mode-of-action groups. Pest Manag. Sci., 65, 969-974. https://doi.org/10.1002/ps.1781

Henderson, G., Walthall, O. M., Wiltz, B. A., Rivera-Montroy, V. H., Ganaway, D. R., \& Selim, H. M. (1998). Analyses of soil properties in relation to termiticide performance in Louisiana. U. Enomology, 65-75.

Husch, P. E., Ferreira, D. G., Seraphim, N., Harvey, N., Silva-Brandão, K. L., \& Sosa-Gomez, D. R. (2018). Structure and genetic variation among populations of Euschistus heros from different geographic regions in Brazil. Entomol. Exp. Appl., 166, 191-203. https://doi.org/10.1111/eea.12666

Jeschke, P., Nauen, R., Schindler, M., \& Elbert, A. (2011). Overview of the status and global strategy for neonicotinoids. J. Agr. Food Chem., 59, 2897-2908. https://doi.org/10.1021/jf101303g

Lahm, G. P., Stevenson, T. M., Selby, T. P., Freudenberger, J. H., Cordova, D., Flexner, L., ... Benner, E. A. (2007). Rynaxypyr: A new insecticidal anthranilic diamide that acts as a potente and selective ryanodine receptor activador. Bioorg. Med. Chem. Lett., 17, 6274-6279. https://doi.org/10.1016/j.bmcl.2007.09.012

Lima, M., Junior, C. A. S., Rausch, L., Gibbs, H. K., \& Johann, J. A. (2019). Demystifying sustainable soy in Brazil. Land Use Policy, 82, 349-352. https://doi.org/10.1016/j.landusepol.2018.12.016

MAPA (Ministério da Agricultura, Pecuária e Abastecimento). (2019). AGROFIT. Retrieved from http://agrofit. agricultura.gov.br/agrofit_cons/principal_agrofit_cons

Mascarenhas, R. N., \& Boethel, D. J. (2000). Development of diagnostic concentrations for insecticide resistance monitoring in soybean looper (Lepidoptera: Noctuidae) larvae using an artificial diet overlay bioassay. $J$. Econ. Entomol., 93, 1-8. https://doi.org/10.1603/0022-0493(2000)093[0897:DODCFI]2.0.CO;2

Milosavljević, I., Esser, A. D., Murphy, K. M., \& Crowder, D. W. (2019). Effects of imidacloprid seed treatments on crop yields and economic returns of cereal crops. Crop Prot., 119, 166-171. https://doi.org/10.1016/ j.cropro.2019.01.027

Moscardi, F., Bueno, A. F., Sosa-Gomez, D. R., Roggia, S., Hoffmann-Campo, C. B., Pomari, A. F., ... Yano, S. A. C. (2012). Artrópodes que atacam folhas da soja. In C. B. Hoffman-Campo, B. S. Corrêa-Ferreira, \& F. Moscardi (Eds.), Soja: Manejo integrado de insetos e outros artrópodes praga (pp. 213-334). Brasília, DF: Embrapa.

Munkvold, G., Sweets, L., \& Wintersteen, W. (2006). Iowa Commercial Pesticide Applicator Manual Category 4. Iowa Commercial Pesticide Application Manual. Iowa State University Extension and Outreach.

Owen, L. N., Catchot, A. L., Musser, F. R., Gore, J., Cook, D. C., \& Jackson, R. (2013). Susceptibility of Chrysodeixis includens (Lepidoptera: Noctuidae) to reduced-risk insecticides. Fla. Entomol., 96, 554-559. https://doi.org/10.1653/024.096.0221

Pereira, C. E., Oliveira, J. A., Guimarães, R. M., Vieira, A. R., Evangelista, J. R. E., \& Oliveira, G. E. (2011). Tratamento fungicida e peliculização de sementes de soja submetidas ao armazenamento. Ciência e Agrotecnologia, 35, 1-7. https://doi.org/10.1590/S1413-70542011000100020

Rodrigues, R. B., Matiuzzi, F. C. P., Assis, J. J., Silva, M. G., Meireles, P. S., \& Silva, F. M. A. (2014). Clorantraniliprole (Dermacor) para o controle de Anticarsia gemmatalis Hubner, 1818 (Lepdoptera: Noctuidae) na cultura da soja. Congresso Brasileiro de Entomologia. Anais eletrônicos... Goiânia.

Rossman, D. V., Byrne, A. M., \& Chilvers, M. I. (2018). Profitability and efficacy of soybean seed treatment in Michigan. Crop Prot., 114, 44-52. https://doi.org/10.1016/j.cropro.2018.08.003 
Santos, A. C., Bueno, A. F., \& Bueno, R. C. O. F. (2006). Seletividade de defensivos agrícolas aos inimigos naturais. In A. S. Pinto, D. E. Nava, M. M. Rossi, \& D. T. Malerbo-Souza (Eds.), Controle biológico de pragas na prática (pp. 221-227).

Santos, L. S., Barbosa, J. C., Aguirre-Gill, O. J., Souza, L. A., Viana, D. L., \& Busoli, A. C. (2017a). Flutuação populacional de lagartas de Anticarsia gemmatalis Hubner (Lepidoptera:Noctuidae) na cultura da soja. Entomol. Mexicana., 4, 326-330.

Santos, S. R., Specht, A., Carneiro, E., Paula-Moraes, S. V., \& Casagrande, M. M. (2017b). Interseasonal variation of Chrysodeixis includens (Walker, [1858]) (Lepidoptera: Noctuidae) populations in the Brazilian Savanna. Rev. Bras. Entomol., 61, 294-299. https://doi.org/10.1016/j.rbe.2017.06.006

Specht, A., Paula-Moraes, S. V., \& Sosa-Gómez, D. R. (2015). Host plants of Chrysodeixis includens (Walker) (Lepidoptera, Noctuidae, Plusiinae). Rev. Bras. Entomol., 59, 343-345. https://doi.org/10.1016/j.rbe.2015. 09.002

Spomer, N. A., Klambe, S. T., \& Siegfried, R. D. (2009). Bioavailability of chrorantraniliprole e indoxacarb to eastern subterranean termites (Isoptera: Rhinotermitidae) in various soils. J. Econ. Entomol., 102, 1922-1927.

Suzana, C. S., Dallagnol, L. C., Fortuna, L. S., Damiani, R., Teston, R., \& Salvadori, J. P. (2017). Potential of antranilic diamides applied in seeds of soybeans with and without crylac protein for Helicoverpa armigera caterpillar control. Afr. J. Agric. Res., 12, 1477-1482. https://doi.org/10.5897/AJAR2017.12124

Szczepaniec, A., Raupp, M. J., Parker, R. D., Kerns, D., \& Eubanks, M. D. (2013). Neonicotinoid insecticides alter induced defenses and increase susceptibility to spider mites in distantly related crop plants. PLoS One, 8, e62620. https://doi.org/10.1371/journal.pone.0062620

Tavares, L. C., Mendonça, A. D., Zanatta, Z. C. N., Brunes, A. P., \& Villela, F. A. (2014). Efeito de fungicidas e inseticidas via tratamento de sementes sobre o desenvolvimento inicial da soja. Enci. Biosfera., 10, 1400-1409.

Thrash, B., Adamczyk, J. J., Lorenz, G., Scott, A. W., Armstrong, J. S., Pfannenstiel, R., \& Taillon, N. (2013). Laboratory evaluations of lepidopteran-active soybean seed treatments on survivorship of Fall Armyworm (Lepidoptera: Noctuidae) larvae. Fla. Entomol., 96, 724-728. https://doi.org/10.1653/024.096.0304

Tonin, R. F. B., Filho, O. A. L., Labbe, L. M. B., \& Rossetto, M. (2014). Potencial fisiológico de sementes de milho híbrido tratadas com inseticidas e armazenadas em duas condições de ambiente. Sci. Agrop., 5, 7-16.

USDA (US Departament of Agriculture). (2019). Retrieved from https://www.ers.usda.gov/topics/crops/ soybeans-oil-crops

Zulin, D., Ávila, C. J., \& Schlick-Souza, E. C. (2018). Population fluctuation and vertical distribution of the soybean looper (Chrysodeixis includens) in soyben culture. Am. J. Plant Sci., 9, 1544-1556. https://doi.org/ 10.4236/ajps.2018.97113

\section{Copyrights}

Copyright for this article is retained by the author(s), with first publication rights granted to the journal.

This is an open-access article distributed under the terms and conditions of the Creative Commons Attribution license (http://creativecommons.org/licenses/by/4.0/). 